\title{
PZ-peptidase activity from ejaculated boar spermatozoa
}

\author{
G. Berruti and R. A. McRorie* \\ Dipartimento di Biologia, Università di Milano, Via Celoria 26, 20133 Milan, Italy and \\ *Department of Biochemistry, University of Georgia, Athens, Georgia 30602, U.S.A.
}

\begin{abstract}
Summary. Protein constituents of the boar spermatozoon were fractionated in three components, the hypotonic soluble fraction, the detergent-soluble fraction, and the detergent-insoluble fraction. When all these fractions were assayed spectrophotometrically using the PZ-peptide as substrate, a high value of PZ-peptidase specific activity was observed in the first fraction. Electrophoretic analysis at $\mathrm{pH} 8.3$ of the protein content from the hypotonic soluble fraction revealed the existence of multiple molecular forms capable of hydrolysing the PZ-peptide. The major form was characterized by a surprisingly high value of electrophoretic mobility, index of the presence of numerous negatively charged residues. Biochemical and ultrastructural analyses showed that the hypotonic soluble fraction did not contain intrinsic, and specifically acrosomal, sperm enzymes.
\end{abstract}

\section{Introduction}

A peptidase that splits collagen peptides and the synthetic collagenase substrate 4-phenylazobenzyloxycarbonyl-Pro-Leu-Gly-Pro-Arg, commonly abbreviated as PZ-peptide, was discovered in human, bull and rat semen by Koren \& Milkovic (1973). The peptidase activity has been partly characterized (Koren, Lukac \& Milkovic, 1974; Koren, Schon \& Lukac, 1975; Lukac \& Koren, 1979), but the localization in the whole ejaculate, the origin, and the physiological function of the enzyme have not yet been elucidated. Lessley \& Garner (1983) used a system that combines differential centrifugation and detergent extraction to study the distribution of the PZ-peptide hydrolysing activity in bovine semen and stated that the cytoplasmic droplets are the major source of PZ-peptidase activity in bovine semen.

In an effort to characterize the enzymic properties of mammalian spermatozoa and to correlate, if possible, these with a specific physiological phenomenon, we have undertaken the present investigation of the distribution of the PZ-peptide hydrolysing activity in boar ejaculated semen. The preliminary enzymic characterization here reported should provide a basis for further biochemical studies including the possible physiological role of such an enzyme.

\section{Materials and Methods}

Chemicals. Synthetic PZ-peptide (4-phenylazo-benzyloxycarbonyl-prolyl-leucyl-glycyl-prolyl-Darginine) and PZ-dipeptide (4-phenylazo-benzyloxycarbonyl-prolyl-leucine) were purchased from Fluka (Milan, Italy). Highly purified collagenase from Clostridium histolyticum (Type VII), benzamidine, $p$-nitrophenol phosphate, $p$-nitrocatechol sulphate, $N$ - $\alpha$-benzoyl-L-arginine ethyl ester (BzArgOEt), $N$-benzoyl-DL-arginine- $\beta$-naphthylamide (BzArgNNab) were from Sigma (St Louis, MO, U.S.A.). Silica gels on aluminium sheets for thin-layer chromatography (t.l.c.) were purchased from Merck (Darmstadt, F.D.R.). Percoll was from Pharmacia Fine Chemicals (Uppsala, Sweden). All other reagents were the best grade available. 
Semen specimens. Semen was collected from healthy boars using an artificial vagina. Sperm counts and qualitative motility determinations were performed by microscopic estimation after liquefaction of the ejaculate at room temperature. The semen was then diluted 1:1 in $63.75 \mathrm{M}$-D-glucose, $39.65 \mathrm{~mm}$-sodium citrate, $20.81 \mathrm{~nm}-\mathrm{NaHCO}_{3}, 6.35 \mathrm{~mm}-\mathrm{EDTA}, 53.65 \mathrm{~mm}-$ Trishydroxymethylaminomethane, $19.75 \mathrm{~mm}$-citric acid, $0.45 \mathrm{~mm}$-cysteine, $0.1 \%(\mathrm{w} / \mathrm{v})$ neomycine sulphate, pH 6.7 (Gottardi \& Brunnel, 1980) to which $50 \mathrm{~mm}$-benzamidine was added, and processed. The addition of benzamidine to the media was made to prevent or retard the activity of acrosin (EC 3.4.21.10), the trypsin-like enzyme peculiar to the mammalian spermatozoon (Zahler \& Polakoski, 1977).

Fractionation of boar semen. Diluted boar semen was centrifuged at $850 \mathrm{~g}$ for $15 \mathrm{~min}$ and the resulting supernatant and pellet were recovered. The supernatant was subjected to another centrifugation $\left(30 \mathrm{~min}\right.$ at $40000 \mathrm{~g}, 4^{\circ} \mathrm{C}$ ) to remove the contaminating particles, such as cytoplasmic droplets, spermatozoa and corpusculate matter. The $40000 \mathrm{~g}$ supernatant was extensively dialysed

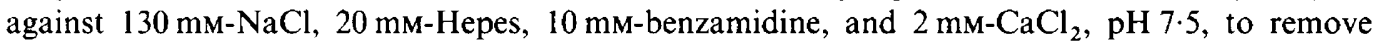
EDTA and cysteine and increase its $\mathrm{pH}$ value from 6.7 to $7 \cdot 5$. The dialysate is referred to as diluted seminal plasma. The $850 \mathrm{~g}$ pellet was carefully resuspended and incubated in a volume, equal to that of original semen, of an hypotonic medium $(75 \mathrm{~mm}-\mathrm{NaCl}, 10 \mathrm{~mm}$-benzamidine, $10 \mathrm{~mm}-\mathrm{Hepes}$, $\mathrm{pH} 7.5$ ) for 10-15 min at room temperature. This step was performed to promote the detachment of the surface components weakly adhered to the sperm plasma membrane (O'Brien \& Bellvè, 1980). To compare the effects of different media on the removal or alteration of the surface antigens of the sperm plasma membrane (Brackett \& Oliphant, 1975), the $850 \mathrm{~g}$ sperm pellets were resuspended and incubated in the same volume of media of various osmolalities, i.e. besides the above hypotonic medium, in an isotonic (140 mM-NaCl, $10 \mathrm{~mm}$-benzamidine, $10 \mathrm{~mm}-\mathrm{Hepes}, \mathrm{pH} 7 \cdot 5)$ and a hypertonic ( $190 \mathrm{~mm}-\mathrm{NaCl}, 10 \mathrm{~mm}$-benzamidine, $10 \mathrm{~mm}$-Hepes, $\mathrm{pH} 7.5)$ medium. The sperm suspension was then centrifuged for $10 \mathrm{~min}$ at $850 \mathrm{~g}$. Again the resulting supernatant and pellet were recovered. The first was centrifuged $30 \mathrm{~min}$ at $40000 \mathrm{~g}, 4^{\circ} \mathrm{C}$; the resulting supernatant is referred to as the hypotonic soluble fraction. The sperm pellet was resuspended in $1 \%$ Triton $\mathrm{X}-100$ in $100 \mathrm{~mm}-\mathrm{NaCl}, 20 \mathrm{~mm}$-Hepes, $50 \mathrm{~mm}$-benzamidine, $1 \mathrm{~mm}-\mathrm{CaCl}_{2}, 1 \mathrm{~mm}$-dithiothreitol, $\mathrm{pH} 7 \cdot 5$, and incubated for $15 \mathrm{~min}$ at $37^{\circ} \mathrm{C}$. The Triton-extracted sperm suspension was centrifuged for $30 \mathrm{~min}$ at $40000 \mathrm{~g}, 4^{\circ} \mathrm{C}$; the resulting supernatant is referred to as the Triton-soluble fraction. The $40000 \mathrm{~g}$ extracted sperm pellet was washed twice in $100 \mathrm{~mm}-\mathrm{NaCl}, 50 \mathrm{~mm}$-benzamidine, $20 \mathrm{~mm}$-Hepes, $1 \mathrm{~mm}-\mathrm{CaCl}_{2}, \mathrm{pH} 7 \cdot 5$, and resuspended in the washing medium. It is referred to as the Tritoninsoluble fraction.

For a preliminary assay of PZ-peptidase activity, other semen preparations, such as whole semen homogenate ( 20 strokes at low speed in a glass Teflon homogenizer) and the Triton extracts of spermatozoa and cytoplasmic droplets, both obtained according to Lessley \& Garner (1983), were checked.

Enzymic assays. PZ-peptidase activity was determined following essentially the method of Wünsch \& Heidrich (1963), with some slight modifications. Samples (1 ml) were mixed with $1 \mathrm{ml}$ $130 \mathrm{~mm}-\mathrm{NaCl}, 20 \mathrm{~mm}-\mathrm{Hepes}, 2 \mathrm{~mm}-\mathrm{CaCl}_{2}, \mathrm{pH} 7 \cdot 5$, containing $0.2 \mathrm{mg}$ PZ-peptide. After incubations of $0,15,30$ and $60 \mathrm{~min}$ at $37^{\circ} \mathrm{C}$, the reaction was stopped by lowering the $\mathrm{pH}$ to 3.0 with $230 \mu \mathrm{l} 0 \cdot 1 \mathrm{~N}-\mathrm{HCl}$ and the released PZ-Pro-Leu was immediately extracted by vigorous shaking with $3 \mathrm{ml}$ ethyl acetate. To promote separation of the phases after extraction, the samples were centrifuged at $600 \mathrm{~g}$ for $5 \mathrm{~min}$ in sealed tubes. Blanks were the extracts from the 0 min reaction mixtures in case some compound was present that might have interfered with the PZ-peptidase activity or with the efficiency of PZ-Pro-Leu extraction. The concentration of the released PZ-dipeptide was determined spectrophotometrically from the absorbance at $320 \mathrm{~nm}$. A standard calibration curve was performed with known concentrations of PZ-dipeptide in ethyl acetate. A unit of activity was defined as the amount of enzyme that releases $1 \mu \mathrm{g}$ PZ-Pro-Leu/min under the above conditions. 
The identification of the split product as PZ-Pro-Leu was established by t.l.c. analysis according to Koren \& Milkovic (1973).

Alkaline phosphatase activity was estimated by extinction at $400 \mathrm{~nm}$ as described by Emmelot, Bos, Benedetti \& Rumke (1964). Arylsulphatase was determined by the method of Roy (1960). Acrosin activity was measured, after extensive dialysis of the samples to remove benzamidine, according to Schwert \& Takenaka (1955).

For the three sperm 'marker' enzymes, one milliunit ( $\mathrm{mU})$ was defined as the amount of enzyme that caused a change in absorbance of 0.001 per minute at the tested wavelengths $(400,515$ and $253 \mathrm{~nm}$ ). A Perkin-Elmer Lambda 3 spectrophotometer, equipped with an Hitachi model 561 recorder, was used.

Electrophoresis. Disc gel electrophoresis at $\mathrm{pH} 8.3$ was performed according to Gabriel (1971). The gels were run at $4^{\circ} \mathrm{C}$ and $2 \mathrm{~mA} /$ gel until the tracking dye migrated $8.5-9 \mathrm{~cm}$ into the gel. Gels were stained for protein according to the 'heavy stain' of Neville \& Glossmann (1974) and for BzArgNNab hydrolysing activity according to Garner (1975).

Electron microscopy. Samples of the sperm pellet after the hypotonic and isotonic (control) treatments were prepared for electron microscopy according to standard techniques. Thin sections were cut on an LKB ultratome and examined in a Philips 400 electron microscope.

Other procedures. Protein concentration was determined spectrophotometrically by the method of Zamenhof (1957). Bovine serum albumin was used to establish a standard curve.

To concentrate diluted samples, immersible CX-10 ultrafiltration membranes $\left(M_{\mathrm{r}}\right.$ cut-off 10000 , from Millipore) were used according to the manufacturer's instructions.

\section{Results}

When assayed using PZ-peptide as substrate, the whole boar homogenate showed a detectable PZ-peptidase activity $(500 \pm 230 \mathrm{mU} / \mathrm{ml}$ semen and $24 \pm 7.5 \mathrm{mU} / \mathrm{mg}$ protein, mean \pm s.d., $n=5$ ). Preliminary semen fractionation (centrifugation at $850 \mathrm{~g}$ ) into the two major components, i.e. seminal plasma and spermatozoa, demonstrated that the main source of the enzyme was the cellular component ( $550 \pm 180 \mathrm{mU} / \mathrm{ml}$ semen and $58 \pm 15 \mathrm{mU} / \mathrm{mg}$ protein). The seminal plasma, however, still contained substantial amounts of contaminants, such as spermatozoa, cytoplasmic droplets, and corpusculate matter; after the centrifugation at $40000 \mathrm{~g}$, no detectable PZ-peptidase activity was found in the contaminant-free seminal plasma.

When the boar semen was fractionated by density gradient centrifugation in Percoll to separate the cytoplasmic droplets from spermatozoa and both fractions were processed and subjected to Triton extraction according to Lessley \& Garner (1983), no detectable PZ-peptidase activity was found in the extract of cytoplasmic droplets, whereas most of the activity was observed in the extract of spermatozoa (data not shown).

When protein constituents of boar spermatozoa were fractionated into three components, i.e. the hypotonic soluble fraction, the Triton-soluble fraction, and the Triton-insoluble fraction, high levels of PZ-peptidase activity were found in the first two fractions (Table 1). However, owing to its high protein content, the PZ-peptidase specific activity of the Triton-soluble fraction was much lower $(<5 \%)$ than that of the hypotonic soluble fraction (Table 1). The PZ-peptidase activity of the detergent-insoluble fraction was very low (Table 1). The treatment with Triton was necessary to extract the second half of PZ-peptide splitting activity. In fact, when the sperm pellet from the first hypotonic treatment was subjected to a second extraction with hypotonic medium, the amount of protein extracted was very limited and negligible PZ-peptidase activity was found in this second hypotonic soluble fraction.

Substantial amounts of PZ-peptidase activity were recovered in the isotonic $(140 \pm 30 \mathrm{mU} / \mathrm{ml}$ semen) and hypertonic $(60 \pm 15 \mathrm{mU} / \mathrm{ml}$ semen) sperm soluble fractions (see 'Materials and 
Table 1. PZ-peptidase activity of the three sperm components from the fractionation procedure

\begin{tabular}{lcc}
\hline Fraction & $\begin{array}{c}\text { PZ-peptidase } \\
\text { (mU/ml semen) }\end{array}$ & $\begin{array}{c}\text { PZ-peptidase } \\
\text { (mU/mg protein) }\end{array}$ \\
\hline $\begin{array}{l}\text { Hypotonic soluble } \\
\text { component }\end{array}$ & $160 \pm 20$ & $440 \pm 40$ \\
$\begin{array}{l}\text { Triton-soluble } \\
\text { component }\end{array}$ & $180 \pm 25$ & $18 \cdot 5 \pm 3 \cdot 5$ \\
$\begin{array}{l}\text { Triton-insoluble } \\
\text { component }\end{array}$ & $15 \pm 2 \cdot 5$ & $9 \pm 2$ \\
\hline
\end{tabular}

Each value represents the mean \pm s.d. of the results from 5 individual fractionation procedures.

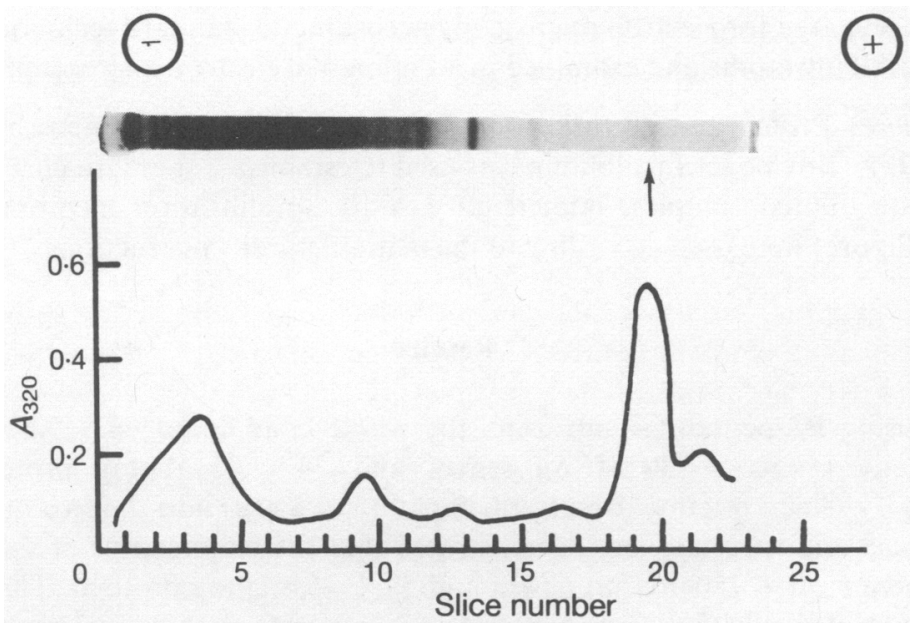

Text-fig. 1. Examination of PZ-peptidase activity of boar spermatozoa by disc gel electrophoresis at $\mathrm{pH} 8 \cdot 3$ of the hypotonic soluble fraction: $80 \mu \mathrm{g}$ protein $(0 \cdot 1 \mathrm{U} \mathrm{PZ}$-peptidase activity) were applied to duplicate $9-\mathrm{cm}$ disc gels of $7.5 \%$ acrylamide with $1-\mathrm{cm}$ stacking gels of $2.5 \%$ acrylamide. One gel was stained with Coomassie Blue (illustrated in upper portion of the figure) and the second was divided into uniform slices $(4 \mathrm{~mm}$ length). These slices were triturated in $100 \mu \mathrm{l}$ buffer at $\mathrm{pH} 7.5\left(140 \mathrm{~mm}-\mathrm{NaCl}, 10 \mathrm{~mm}-\mathrm{Tris}, 10 \mathrm{~mm}-\mathrm{CaCl}_{2}\right)$ and then incubated in the presence of the PZ-peptide (final concentration $0.1 \mathrm{mg} / \mathrm{ml} \mathrm{buffer}$ ) for a prolonged period $\left(3 \mathrm{~h}, 37^{\circ} \mathrm{C}\right)$ and examined spectrophotometrically. The arrow indicates the dye front.

Table 2. Enzymic activities* in hypotonic and Triton-soluble sperm fractions

\begin{tabular}{lccc}
\hline Fraction & $\begin{array}{c}\text { Alkaline phosphatase } \\
(\mathrm{mU} / \mathrm{ml} \text { semen })\end{array}$ & $\begin{array}{c}\text { Arylsulphatase } \\
(\mathrm{mU} / \mathrm{ml} \text { semen })\end{array}$ & $\begin{array}{c}\text { Acrosin } \\
(\mathrm{mU} / \mathrm{ml} \text { semen })\end{array}$ \\
\hline $\begin{array}{c}\text { Hypotonic soluble } \\
\text { component }\end{array}$ & 24.44 & 1.83 & Not detectable \\
$\begin{array}{c}\text { Triton-soluble } \\
\text { component }\end{array}$ & 391.0 & 21.55 & 132 \\
\hline
\end{tabular}

*For definition of units, see text. 
Methods'); it therefore appeared that a simple washing and incubation of spermatozoa with saline solution was sufficient to detach PZ-peptidase activity.

The electrophoretic analyses of the hypotonic soluble fraction revealed the presence of about 15 major protein species, 3 peaks of PZ-peptide hydrolysing activity (Text-fig. 1). The largest of these peaks was characterized by a surprisingly high electrophoretic mobility (its $R_{\mathrm{f}}$ value was similar to that of the dye) and was just revealed by the protein staining. The other peaks of PZ-peptide hydrolysing activity were localized in the top and middle gel fractions; their distribution could be correlated with that of some blue-stained bands. An apparently analogous distribution of the peaks of activity was found in the gels loaded with the Triton-soluble fraction, but the peaks were broad and good separation of the protein content was not obtained because of difficulties of penetration into the gel at $\mathrm{pH} 8 \cdot 3$ (data not shown).

The biochemical investigation to test the presence of sperm 'marker' enzymes in the hypotonic soluble fraction is summarized in Table 2. Low alkaline phosphatase and arylsulphatase activities were found; no acrosin activity was detected. This last result was confirmed also by the electrophoretic analysis performed to detect BzArgNNab hydrolysing activity on the gel loaded with a sample of the hypotonic soluble fraction. Since alkaline phosphatase is an enzyme 'marker' for plasma membranes (Emmelot et al., 1964), while arylsulphatase and acrosin are enzymes peculiar to the soluble (Allison \& Hartree, 1970) and membranous (Berruti \& Martegani, 1984) acrosomal contents, the enzymic activities of the hypotonic soluble fraction would appear to be attributable neither to intrinsic sperm plasma membrane nor to acrosomal components.

The biochemical data were confirmed by ultrastructural analysis. Ten grid squares ( $200 \mathrm{mesh})$ on each section were selected at random, and all the spermatozoa on any one of these squares were scored for membrane integrity. The results ( 300 spermatozoa per specimen) revealed no remarkable differences between the morphology of the control and hypotonically treated spermatozoa. When there was loss of membrane integrity (about $20 \%$ of the sperm population) it was limited to the plasma membrane covering the head. The acrosomal contents and the acrosomal membranes were unaffected.

\section{Discussion}

Amongst the variety of proteolytic enzymes found to be sperm associated, the present study revealed the presence of activities hydrolysing the PZ-peptide in boar semen. The fractionation procedure utilized indicates that a large amount of such activities is loosely adsorbed to the sperm surface. This suggestion is supported by other data obtained in our preliminary attempt to characterize PZ-peptidase activity.

Intact spermatozoa possess a net negative charge (Nevo, Michaeli \& Schindler, 1961) and there is a marked increase in negative surface charge as spermatozoa mature (Bedford, 1963). The electrophoretic behaviour of the protein content from the hypotonic soluble fraction at $\mathrm{pH} 8.3$ indicates a remarkable abundance of negatively charged residues in the molecular species responsible for the major PZ-peptidase activity. Indeed, this property seems to be common to the animal PZ-peptidases (see the PZ-peptidase from tadpole tissues found by Harper \& Gross (1970) and the PZ-peptidase from chick embryos reported by Morales \& Wöessner (1977)). Moreover, the electrophoretic analysis here reported has revealed the existence of more molecular species able to split the PZ-peptide in boar semen. However, it is not possible, on the basis of the present data, to establish whether these species are due to multiple molecular forms of a specific PZ-peptidase activity or to different enzymes that show a PZ-peptide hydrolysing activity. The existence of more forms able to split the PZ-peptide could explain the difficulty of establishing the precise localization of the PZ-peptidase from male semen. This may be valid not only for the present work, but also for the previous ones (Koren \& Milkovic, 1973; Koren et al., 1974, 1975; Lukac \& Koren, 1979; Lessley \& Garner, 1983) in which the PZ-peptidase activity was observed in all the isolated seminal fractions, 
including the sperm washings. Lessley \& Garner (1984) have reported the presence of different PZ-peptidases in bovine semen.

Finally, both the biochemical investigation to detect specific sperm activities and the ultrastructural analysis to verify the possible damage of the hypotonic treatment to sperm membranes integrity exclude an acrosomal, and probably intrinsic, localization of the PZ-peptide splitting activity(s) in the hypotonic soluble fraction of boar semen. A non-sperm origin of such activity(s) can therefore be considered.

We thank Ente Lombardo-Potenziamento Zootecnico Zorlesco, Milano, for gifts of semen samples. This work was supported by a C.N.R. grant, Bilateral Project No. 84.01800.04.

\section{References}

Allison, A.C. \& Hartree, E.F. (1970) Lysosomal enzymes in the acrosome and their possible role in fertilization. J. Reprod. Fert. 21, 501-515.

Bedford, J.M. (1963) Changes in the electrophoretic properties of the rabbit spermatozoa during passage through the epididymis. Nature, Lond. 200, 1178-1180.

Berruti, G. \& Martegani, E. (1984) Dansylalanyllysylchloromethylketone as a fluorescent probe for localization of acrosin activity in boar and human spermatozoa. J. Histochem. Cytochem. 32, 526-531.

Brackett, B.G. \& Oliphant, G. (1975) Capacitation of rabbit spermatozoa in vitro. Biol. Reprod. 12 , 260-274.

Emmelot, P., Bos, C.J., Benedetti, E.L. \& Rumke, Ph. (1964) Studies on plasma membranes. I. Chemical composition and enzyme content of plasma membranes isolated from rat liver. Biochim. Biophys. Acta 90, 126-145.

Gabriel, O. (1971) Analytical disc gel electrophoresis. In Methods in Enzymology, Vol. 22, pp. 565-578. Ed. W. B. Jakoby. Academic Press, New York.

Garner, D.L. (1975) Improved zymographic detection of bovine acrosin. Analyt. Biochem. 67, 688-694.

Gottardi, L. \& Brunnel, L. (1980) New dilution media for artificial insemination in pig. Proc. 9th Int. Congr. Anim. Reprod. \& A.I., Madrid p. 49.

Harper, E. \& Gross, J. (1970) Separation of collagenase and peptidase activities of tadpole tissues in culture. Biochim. Biophys. Acta 198, 286-292.

Koren, E. \& Milkovic, S. (1973) Collagenase-like peptidase in human, rat and bull spermatozoa. $J$. Reprod. Fert. 32, 349-356.

Koren, E., Lukac, J. \& Milkovic, S. (1974) The effect of collagenase-like peptidase from rat testis and clostridial collagenase on the rat seminal vesicle secretion and its coagulation. J. Reprod. Fert. 36, 161-167.

Koren, E., Schon, E. \& Lukac, J. (1975) The coagulation of insoluble and basic protein from rat seminal secretion with vesiculase: influence of collagenase-like peptidase from rat testis. J. Reprod. Fert. 42, $491-495$.
Lessley, B.A. \& Garner, D.L. (1983) Distribution of PZ-peptidase in bovine epididymal and ejaculated semen. Biol. Reprod. 28, 447-459.

Lessley, B.A. \& Garner, D.L. (1984) Identification and preliminary characterization of two distinct bovine seminal PZ-peptidases. Biol. Reprod. 31, 353-369.

Lukac, J. \& Koren, E. (1979) Mechanism of liquefaction of the human ejaculate. II. Role of collagenase-like peptidase and seminal proteinase. J. Reprod. Fert. 56, 50I-506.

Morales, T.I. \& Woessner, J.F., Jr (1977) PZ-peptidase from chick embryos. J. biol. Chem. 252, 4855-4860.

Neville, D.M. \& Glossmann, H. (1974) Molecular weight determination of membrane protein and glycoprotein subunits by discontinuous gel electrophoresis in dodecyl sulfate. In Methods in Enzymology, Vol. 32, pp. 92-102. Eds S. Fleischer \& L. Packer. Academic Press, New York.

Nevo, A.C., Michaeli, I. \& Schindler, H. (1961) Electrophoretic properties of bull and rabbit spermatozoa. Expl Cell Res. 23, 69-83.

O'Brien, D.A. \& Bellvè, A.R. (1980) Protein constituents of the mouse spermatozoon. I. An electrophoretic characterization. Devl Biol. 75, 386-404.

Roy, A.B. (1960) The sulphatase of ox liver 7. The intracellular distribution of sulphatases A and B. Biochem. J. 77, 380-386.

Schwert, G.W. \& Takenaka, Y. (1955) A spectrophotometric determination of trypsin and chymotrypsin. Biochim. Biophys. Acta 16, 570-575.

Wünsch, E. \& Heidrich, H.G. (1963) Zur quantitativen Bestimmung der Kollagenase. Hoppe-Seyler's $Z$. Physiol. Chem. 333, 149-151.

Zahler, W.L. \& Polakoski, K.L. (1977) Benzamidine as an inhibitor of proacrosin activation in bull sperm. Biochim. Biophys. Acta 480, 461-468.

Zamenhof, S. (1957) Preparation and assay of deoxyribonucleic acid from animal tissue. In Methods in Enzymology, Vol. 3, pp. 696-704. Eds S. P. Colowick \& N. O. Kaplan. Academic Press, New York.

Received 3 December 1984 